\title{
Influence of industrial contamination on mobile genetic elements: class 1 integron abundance and gene cassette structure in aquatic bacterial communities
}

\author{
Meredith S Wright ${ }^{1}$, Craig Baker-Austin ${ }^{1}$, Angela H Lindell ${ }^{1}$, Ramunas Stepanauskas ${ }^{2}$, \\ Hatch W Stokes ${ }^{3}$ and J Vaun McArthur ${ }^{1}$ \\ ${ }^{1}$ Savannah River Ecology Laboratory, University of Georgia, Aiken, SC, USA; ${ }^{2}$ Bigelow Laboratory for Ocean \\ Sciences, West Boothbay Harbor, ME, USA and ${ }^{3}$ Department of Chemistry and Biomolecular Sciences, \\ Macquarie University, Sydney, New South Wales, Australia
}

\begin{abstract}
The acquisition of new genetic material via horizontal gene transfer allows bacteria to rapidly evolve. One key to estimating the contribution of horizontal gene transfer to bacterial evolution is to quantify the abundance of mobile genetic elements (MGEs) in bacterial communities under varying degrees of selective pressure. We quantified class 1 integrase (int/1) gene abundance in total community DNA extracted from contaminated and reference riverine and estuarine microhabitats, and in metal- or antibiotic-amended freshwater microcosms. The intl1 gene was more abundant in all contaminant-exposed communities indicating that relative gene transfer potential is higher in these communities. A second key to assessing the contributions of MGEs to bacterial evolution is to examine the structure and function of the MGE-associated gene pool. We determined that the gene cassette pool is a novel and diverse resource available for bacterial acquisition, but that contamination has no discernible effect on cassette richness. Gene cassette profiles were more similar within sites than among sites, yet bacterial community profiles were not, suggesting that selective pressures can shape the structure of the gene cassette pool. Of the 46 sequenced gene cassette products, 37 were novel sequences, while the 9 gene cassettes with similarity to database sequences were primarily to hypothetical proteins. That class 1 integrons are ubiquitous and abundant in environmental bacterial communities indicates that this group of MGEs can play a substantial role in the acquisition of a diverse array of gene cassettes beyond their demonstrated impact in mediating multidrug resistance in clinical bacteria.
\end{abstract}

The ISME Journal (2008) 2, 417-428; doi:10.1038/ismej.2008.8; published online 14 February 2008

Subject Category: evolutionary genetics

Keywords: class 1 integron; gene cassette; mobile genetic element; metals; environment

\section{Introduction}

Mobile genetic elements (MGEs) involved in bacterial acquisition and recombination of foreign DNA contribute to genetic diversity within bacterial assemblages and enable bacteria to rapidly evolve (Ochman et al., 2000; O'Brien, 2002; Dobrindt et al., 2004; Gogarten and Townsend, 2005; Boucher et al., 2007). Previous approaches to examine the role of horizontal gene transfer in microbial evolution have

Correspondence: Current address: MS Wright, Flathead Lake Biological Station, University of Montana, 32125 Bio Station Lane, Polson, MT 59860, USA.

E-mail: meredith.wright@umontana.edu

Received 24 August 2007; revised 4 January 2008; accepted

8 January 2008; published online 14 February 2008 involved the use of a comparative approach to reconstruct historical gene transfer events (for example, Boucher et al., 2003; Kunin et al., 2005; Comas et al., 2006; Doolittle and Bapteste, 2007), the use of in vivo or in vitro gene transfer experiments where gene transfer rates are estimated under controlled conditions (for example, Dahlberg et al., 1998; van Elsas and Bailey, 2002) or molecular investigations of cellular regulation and machinery involved in the process (for example, Thorsted et al., 1998; Lambertsen et al., 2004). While these methods have merit for revealing evolutionary relationships among organisms and the mechanisms that lead to transfer, they rarely reflect in situ gene transfer potential in microbial assemblages.

One key to estimating gene transfer potential and its role in bacterial evolution is to first estimate MGE 
abundance in bacterial communities under varying degrees of selective pressure. Several studies have detected MGEs including plasmids, transposons and integrons across a wide variety of habitats (for example, Sobecky, 1999; Smalla and Sobecky, 2002; van Elsas and Bailey, 2002; Frost et al., 2005), but rarely in a quantitative manner due to previous methodological constraints. In those studies that did quantify MGE abundance in bacterial communities, class 1 integrase (intI1) genes were shown to be abundant in Gram-positive and Gram-negative bacteria in poultry litter obtained from farms with varying antibiotic usage regimes regardless of antibiotic usage (Nandi et al., 2004), while mercury exposure was recently demonstrated to increase the abundance of IncP-1 plasmids (Smalla et al., 2006). Yet, how MGE abundance is affected by environmental conditions and selective pressures is poorly understood and remains to be tested systematically.

In this study, we examined the potential contribution of integrons to bacterial evolution under varying degrees of selective pressure from metal exposure. Integrons are genetic elements that incorporate exogenous sources of mobile DNA called gene cassettes into the recipient genome via site-specific recombination. Various classes of integrons have been identified (Nield et al., 2001; Nemergut et al., 2004; Boucher et al., 2007), but each class shares a common structure including an integrase gene (intI) that encodes for the enzyme catalyzing the site-specific recombination of a gene cassette at an integron-associated site designated attI. Where examined, integrons also possess a promoter, $\mathrm{P}_{\mathrm{c}}$ that allow the transcription of the typically promoterless open reading frames (ORFs) contained within adjacent gene cassettes (Figure 1). The units of insertion into integrons are gene cassettes. These are independently mobilizable genetic units that normally consist of a single ORF and a cassette-associated recombination site designated a 59-base element or attC. Class 1 integrons were first identified due to their role in the

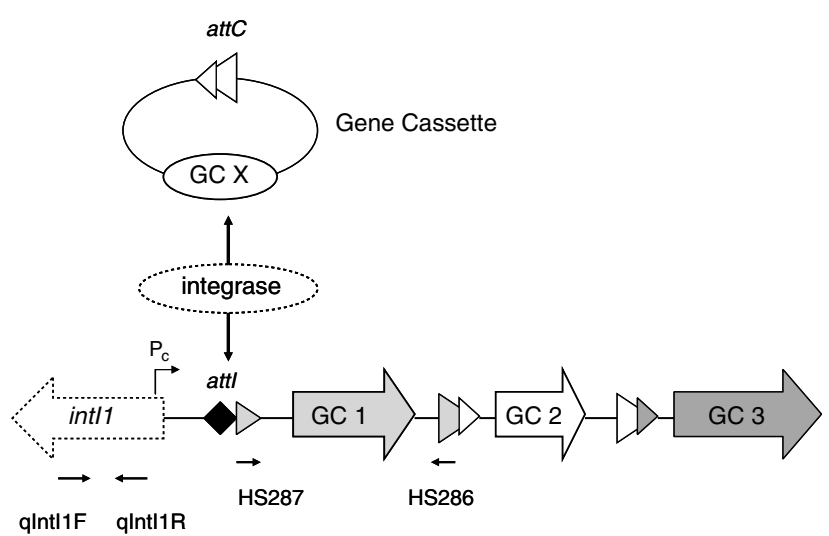

Figure 1 Structure and orientation of integrons. The integrase enzyme, intI, catalyzes the site-specific recombination of the gene cassette (GC) attC site at the attI location within the integron downstream of the promoter, $\mathrm{P}_{\mathrm{c}}$. dissemination of antibiotic resistance gene cassettes in clinical bacteria (Stokes and Hall, 1989), but have since been found in a phylogenetically broad range of clinical and environmental bacteria including Gram-negative and Gram-positive bacteria (Nandi et al., 2004; Stokes et al., 2006; Boucher et al., 2007). Environmental surveys of integron-associated gene cassettes indicate that the majority of cassettes include novel sequences unrelated to known antibiotic resistance genes (Stokes et al., 2001; Holmes et al., 2003), with one conservative estimate of cassette richness being at least 2343 different gene cassettes in a $50-\mathrm{m}^{2}$ sediment plot (Michael et al., 2004). Integrons therefore represent a potential genetic resource by which bacteria in a variety of environments can adapt through the acquisition of new genetic material.

To estimate the potential contribution of integrons to the evolution of aquatic bacteria, we compared the relative abundance of class 1 integrons and examined the structure and function of the gene cassette pool in aquatic microbial communities under varying degrees of contaminant exposure. We compared the abundance of intI1 genes in bacterial communities from industrially contaminated and reference riverine and estuarine systems, and in freshwater microcosms where bacterial exposure to metals and antibiotics was directly manipulated. To further investigate how environmental conditions influence the structure and function of genes contained within integrons, we compared gene cassette diversity and similarity metrics using gene size fragment analysis, and assessed their predicted function through sequence analysis.

\section{Materials and methods}

\section{Sampling}

Savannah River Site. We collected samples from two streams located on the United States Department of Energy's Savannah River Site (SRS) near Aiken, SC, USA on 9 November 2005. Effluent from ash-settling basins associated with the SRS D-400 coal-fired power plant enters into Beaver Dam Creek at a site designated Site A, the first sampling point. Sediment here consists of cobble, sand and coal ash particles with elevated concentrations of a variety of metals associated with coal ash effluent including selenium, arsenic and strontium (Wright et al., 2006). Beaver Dam Creek Site D is located $3.2 \mathrm{~km}$ downstream from Site A, where sediment is primarily sandy, and dissolved metal concentrations are typically lower than at Site A. Meyers Branch is a historically unimpacted blackwater stream with sandy sediment, which has previously been used as a reference stream on the SRS (McArthur and Tuckfield, 2000; Wright et al., 2006). Neither stream has a point source of anthropogenic antibiotics.

We collected bacteria from four common stream microhabitats to examine the abundance of MGEs 
in a variety of microbial communities including epiphytic biofilm, Corbicula fluminea (Asiatic Clam) digestive tracts, surface sediments and surface water. Epiphytic biofilm was collected from oak wooden dowels $(2 \times 45 \mathrm{~cm})$ deployed at each site on 3 June 2005. On the sampling date, we transported three dowels from each site back to the laboratory in sterile whirlpacks on ice for further processing. To represent microbial communities harbored in the digestive tract of invertebrates, we collected nine C. fluminea individuals. Grab samples of surface sediments were collected in triplicate in sterile whirlpacks to analyze sediment bacterial communities, and we collected $1 \mathrm{l}$ of stream water in triplicate in autoclaved and UVsterilized polycarbonate bottles to sample bacterial communities in the water column.

Estuarine sites. We sampled three estuaries located along the Georgia and South Carolina coasts that vary in degree and type of industrial contamination in October 2005. Both Shipyard Creek (Charleston, SC, USA) and the LCP Site (Brunswick, GA, USA) are designated on the US Environmental Protection Agency National Priorities List for their history of hazardous industrial contamination. Sediments contain elevated concentrations of chromium and cadmium (Shipyard Creek), and mercury (LCP Chemical) among other contaminants. The AshepooCombahee-Edisto (ACE) Basin estuary (Beaufort, SC, USA), a historically unimpacted US National Wildlife Refuge, served as a reference site. We collected samples in triplicate as above for surface sediments and water samples during both ebb and flood tides.

Savannah River microcosms. Bacterial exposure to metals and antibiotics was experimentally manipulated using a series of freshwater microcosms conducted by (Stepanauskas et al., 2006). We collected surface water from the Savannah River near the intake for the SRS D-400 coal-fired power plant on 29 September 2003, which was then aliquoted into triplicate tetracycline $\left(30 \mathrm{mgl}^{-1}\right)$, cadmium (0.1 mM) or control microcosms. Selected concentrations represent treatment microcosms from Stepanauskas et al. (2006) that generated an increase in metal and antibiotic resistance phenotypes relative to controls in the microcosm series. Microcosms were incubated for 7 days at $23^{\circ} \mathrm{C}$ with slow rotation (100 r.p.m. on an orbital shaker) after which $250 \mathrm{ml}$ of water were collected for DNA extraction.

\footnotetext{
Metal analysis

Sediment samples were collected from each site to confirm that a gradient of metal concentrations existed among sites. Sediment samples were frozen until processing as in Wright et al. (2006) at the Savannah River Ecology Laboratory analytical
}

facility and analyzed using ICP-MS with the appropriate calibration standards and blanks during digestion and analysis.

\section{Sample processing}

Samples were processed immediately in the laboratory. For biofilm samples, we aseptically scraped biofilm material from the wooden dowels using a sterilized razor blade and extracted DNA from $0.25 \mathrm{~g}$ of this material using the MoBio PowerSoil DNA Extraction kit according to the manufacturer's instructions. To extract DNA from Corbicula digestive tracts, we aseptically removed and combined the hindguts of three individuals per replicate to obtain enough material to process using the MoBio UltraClean DNA Extraction kit. We extracted sediment DNA from $0.4 \mathrm{~g}$ of sediment using the MoBio PowerSoil DNA Extraction kit. For water samples, we filtered $1 \mathrm{l}$ of water (or $250 \mathrm{ml}$ for the microcosms), onto $0.2 \mu \mathrm{m}$ filters. Because of suspended particles, multiple filters had to be used that were combined in $50 \mathrm{ml}$ Eppendorf tubes containing $10 \mathrm{ml}$ of autoclaved, UV-sterilized nanopure water. Tubes were votexed until all visible particles were detached and centrifuged at $4700 \mathrm{~g}$ for $15 \mathrm{~min}$ to pellet bacteria. We extracted DNA from the pellets using MoBio UltraClean DNA Extraction kit. DNA was quantified using gel standards with AlphaEaseFC Software version 3.1.2 (Alpha Innotech Corp., San Leandro, CA, USA).

\section{Quantitative PCR protocol}

Primers. Primers targeting the intI1 gene were designed to estimate the abundance of class 1 integrons (Figure 1). To account for potential differences among samples in bacterial abundance and PCR inhibitors, universal primers were also used to quantify 16S rRNA genes as used in Fierer et al. (2005). Primers used and their annealing temperatures are detailed in Table 1.

Calibration standards. Calibration standards for use in quantitative PCR (qPCR) assays were generated from conventional PCR products using the appropriate primer pair with DNA extracted from each sample type as the template. We purified PCR products using the Qiagen PCR Purification kit according to the manufacturer's instructions, and purified amplicons were then quantified using AlphaEaseFC software. Six 10-fold dilutions were subsequently prepared with each purified PCR product for use as standards in qPCR assays.

Quantitative PCR conditions. Quantitative PCR for intI1 and 16S rRNA genes consisted of $1 \mu \mathrm{l}$ template, $1 \mu \mathrm{l}$ of each $1 \mu \mathrm{M}$ intI1 primer $(10 \mu \mathrm{M}$ 16S rRNA primers), $12.5 \mu$ l of SuperArray SYBR Green Master Mix (SuperArray, Frederick, MD, USA), and PCRgrade water to a reaction volume of $25 \mu \mathrm{l}$. Triplicate 
Table 1 Primers used in this study used conventional and quantitative PCR (qPCR) reactions, expected amplicon size and annealing temperature

\begin{tabular}{|c|c|c|c|c|c|c|}
\hline Target & PCR type & Primer & Sequence $\left(5^{\prime} \rightarrow 3^{\prime}\right)$ & $\begin{array}{l}\text { Amplicon } \\
\text { size (bp) }\end{array}$ & $\begin{array}{c}\text { Annealing } \\
\text { temperature } \\
\left({ }^{\circ} \mathrm{C}\right)\end{array}$ & Reference \\
\hline \multirow[t]{2}{*}{ intI1 } & \multirow[t]{2}{*}{ qPCR } & qIntI1F & ACCAACCGAACAGGCTTATG & \multirow[t]{2}{*}{$\sim 286$} & \multirow[t]{2}{*}{62} & \multirow[t]{2}{*}{$\begin{array}{l}\text { Nemergut et al. } \\
(2004)\end{array}$} \\
\hline & & qIntI1R & GAGGATGCGAACCACTTCCAT & & & \\
\hline \multirow[t]{2}{*}{$a t t C$} & \multirow[t]{2}{*}{ Conventional } & HS286 & $\begin{array}{l}\text { (FAM)-ATCCTCSGCTKGARCGA } \\
\text { MTTGTTAGVC }\end{array}$ & \multirow[t]{2}{*}{ Variable } & \multirow[t]{2}{*}{55} & \multirow[t]{2}{*}{$\begin{array}{l}\text { Stokes et al. } \\
(2001)\end{array}$} \\
\hline & & HS287 & GGGATCCGCSGCTKANCTCVRRCGTTAGSC & & & \\
\hline \multirow[t]{2}{*}{ 16s rRNA } & \multirow[t]{2}{*}{ qPCR } & Eub338 & ACTCCTACGGGAGGCAGCAG & \multirow[t]{2}{*}{$\sim 200$} & \multirow[t]{2}{*}{63} & \multirow[t]{2}{*}{$\begin{array}{l}\text { Fierer et al. } \\
(2005)\end{array}$} \\
\hline & & Eub518 & ATTACCGCGGCTGCTGG & & & \\
\hline \multirow[t]{2}{*}{ 16s rRNA } & \multirow[t]{2}{*}{ Conventional } & $\mathrm{E} 334 \mathrm{~F}$ & (FAM)-CCAGACTCCTACGGGAGGCAGC & \multirow[t]{2}{*}{$\sim 605$} & \multirow[t]{2}{*}{55} & \multirow[t]{2}{*}{$\begin{array}{l}\text { Baker et al. } \\
(2003)\end{array}$} \\
\hline & & E939R & CTTGTGCGGGCCCCCGTCAATTC & & & \\
\hline
\end{tabular}

reactions for each sample were performed using the Bio-Rad iQCycler Real-Time Detection System in Bio-Rad iCycler 96-well plates, where triplicate no-template controls were also used. The thermocycler protocol for intI1 and 16S rRNA reactions consisted of $95{ }^{\circ} \mathrm{C}$ for $15 \mathrm{~min}$, followed by 40 cycles of $95^{\circ} \mathrm{C}$ for $30 \mathrm{~s}, 62{ }^{\circ} \mathrm{C}$ for $30 \mathrm{~s}\left(53^{\circ} \mathrm{C}\right.$ for $16 \mathrm{~S}$ rRNA), $72{ }^{\circ} \mathrm{C}$ for $30 \mathrm{~s}$ and a final $10 \mathrm{~min}$ at $72^{\circ} \mathrm{C}$ for extension. To ensure specificity for each reaction, multiple analyses were conducted. A melt curve was analyzed after each qPCR run, while randomly selected samples were run on a $1 \%$ agarose gel in $10 \times$ TBE solution for $30 \mathrm{~min}$ at $80 \mathrm{~V}$ to check for the presence of a single band of the appropriate size, and an additional subset of intI1 PCR products were selected for sequencing (see below). Copy number of each target gene was calculated using the average molecular mass of $660 \mathrm{~g} \mathrm{~mol}^{-1}$ for a double-stranded DNA molecule. Estimates of 16S rRNA copy number were corrected for amplification in no-template control reactions.

\section{Gene cassette profiling}

To assess the structure of the gene cassette community, fluorescently labeled primers targeting the $a t t C$ site (HS286 and HS287 in Figure 1) were used to amplify gene cassettes from freshwater and estuarine sediment samples and microcosms as in Michael et al. (2004). PCRs were run in triplicate for each sample consisting of $400 \mathrm{nM}$ of each primer, $10 \times$ PCR buffer, $1.5 \mathrm{mM} \mathrm{MgCl}_{2}, 200 \mu \mathrm{M}$ dNTPs, $0.02 \mathrm{U}$ JumpStart Taq (Sigma-Aldrich, St Louis, MD, USA) and $5 \mathrm{ng}$ of template DNA in a $25-\mu \mathrm{l}$ reaction volume. PCR conditions were as follows: $95{ }^{\circ} \mathrm{C}$ for $10 \mathrm{~min}$, followed by 35 cycles of $95^{\circ} \mathrm{C}$ for $1 \mathrm{~min}, 55^{\circ} \mathrm{C}$ for $30 \mathrm{~s}, 72{ }^{\circ} \mathrm{C}$ for $2 \mathrm{~min} 30 \mathrm{~s}$ and a final extension at $72{ }^{\circ} \mathrm{C}$ for $10 \mathrm{~min}$. PCR amplicons were subsequently analyzed using fragment analysis on an ABI 3130xl sequencer to separate gene cassettes by size, combining $1 \mu \mathrm{l}$ of PCR product with $1.5 \mu \mathrm{l}$ internal NAUROX size standard (to $1002 \mathrm{bp}$ ) (DeWoody et al., 2004) and $7.5 \mu \mathrm{l}$ of HiDi/formamide. We limited analysis of cassette sizes to those within 250-999 bp, as the false-positive rate for PCR fragments smaller than $250 \mathrm{bp}$ increases significantly (as determined from our sequencing results and as in Michael et al., 2004), and size class calling accuracy decreases with increasing amplicon size. To account for variability among PCR experiments, three triplicate PCRs were analyzed separately for each sample using GeneMapper (Applied Biosystems, Foster City, CA, USA) with the peak detection algorithm set to detect peaks greater than 20 fluorescence units above the threshold. We compiled the data from the three runs by retaining peaks that were present in at least two out of the three PCR runs and calculated mean peak area as a measure of relative cassette abundance.

\section{tRFLP analysis}

We assessed bacterial community structure by amplifying 16S rRNA fragments for terminal restriction length polymorphism (tRFLP) analysis. PCR mixture consisted of $400 \mathrm{nM}$ of the universal primers 5'-FAM labeled E334F and unlabeled E939R (Table 1), $10 \times$ PCR buffer, $1.5 \mathrm{mM} \mathrm{MgCl}_{2}, 200 \mu \mathrm{M}$ dNTPs, $0.02 \mathrm{U}$ JumpStart Taq (Sigma) and $5 \mathrm{ng}$ of template DNA. The thermocycler program consisted of $95{ }^{\circ} \mathrm{C}$ for $10 \mathrm{~min}$, followed by 35 cycles of $95^{\circ} \mathrm{C}$ for $1 \mathrm{~min}, 55^{\circ} \mathrm{C}$ for $30 \mathrm{~s}, 72^{\circ} \mathrm{C}$ for $1 \mathrm{~min}$ and a final extension at $72{ }^{\circ} \mathrm{C}$ for $10 \mathrm{~min}$. Duplicate PCRs were run for each sample, combined and purified using QIAquick PCR Purification kit (Qiagen, Valencia, CA, USA) according to the manufacturer's instructions. PCR products were subsequently quantified using DNA standards and the AlphaImager system and software. To generate restriction fragments, we incubated $30 \mathrm{ng}$ of PCR product with $1 \mu \mathrm{l}$ of RsaI enzyme (New England Biolabs, Ipswich, MA, USA) (RsaI was demonstrated to generate the most peaks 
in initial testing of samples), $2 \mu \mathrm{l}$ of NEBuffer 1, and water to a reaction volume of $20 \mu \mathrm{l}$ at $37^{\circ} \mathrm{C}$ for $1 \mathrm{~h}$, followed by $20 \mathrm{~min}$ as $65^{\circ} \mathrm{C}$ to inactivate the enzyme. Ten microliters of the products were then purified, precipitated and resuspended in TE following the methods of Sambrook and Russell (2000). For fragment analysis on the ABI 3130xl sequencer, we denatured $1 \mu \mathrm{l}$ of the purified digest product with $0.7 \mu \mathrm{l}$ of NAUROX internal size standard and $13 \mu \mathrm{l}$ of $1: 1 \mathrm{HiDi} /$ formamide at $95{ }^{\circ} \mathrm{C}$ for $5 \mathrm{~min}$. Peaks above 20 fluorescence units were detected and sized using a global Southern algorithm in GeneMapper software (Applied Biosystems).

\section{Sequencing}

We assessed potential gene cassette function by transforming gene cassette PCR products from one randomly selected sample of each sample type (for example, Savannah River Site sediment, Shipyard Creek ebb tide, tetracycline microcosm and so on) into sequencing vectors using TOPO TA Cloning Kit (Invitrogen, Carlsbad, CA, USA). Clones were screened for the presence of the insert using conventional PCR with M13 primers. We then analyzed PCR products on a 1\% agarose gel for $30 \mathrm{~min}$ at $80 \mathrm{~mA}$ and selected clones for sequencing representing a range of sizes. Sequencing reactions using M13 forward and reverse primers and BigDye 3.1 Terminators (Applied Biosystems) were resolved on an ABI 3130xl sequencer. We joined contigs and manually edited sequences using Sequencher software (GeneCodes, Ann Arobr, MI, USA) to ensure accuracy of the readings. After confirming the presence of both HS286 and HS287 primer sequences in the obtained sequences, we both manually identified predicted ORFs and used NCBI's ORF Finder (www.ncbi.nlm.nih.gov/gorf/ gorf.html) to locate predicted proteins within gene cassettes. To assess potential function of predicted proteins, we conducted a BLASTX search to identify similar amino-acid sequences (Altschul et al., 1990).

The intI1 qPCR products were also transformed with the TOPO TA Cloning Kit and sequenced using M13 primers as above to verify amplification of the correct target.
Statistical analyses and gene cassette diversity and similarity metrics

Differences among sites in log-transformed integrase relative abundance (intI1 copy number/16S rRNA copy number) were analyzed by analysis if variance in SAS (SAS Institute, Cary, NC, USA), where site was the main effect. Site means were compared using the LSMEANS option with $\alpha=0.05$. Each sample set (freshwater, estuarine and microcosms), and each microhabitat were analyzed separately because of potential differences in PCR efficiencies and inhibitors among different bacterial community types.

Gene cassette richness, Shannon diversity and community similarity values (Chao's abundancebased Jaccard similarity) were calculated using EstimateS software version 7.5 (Colwell, 2005). Richness (the number of detected gene cassette sizes) and diversity values were calculated for each site using compiled data from the three replicate PCRs for each sample. A distance matrix was constructed for gene cassette profiles from each sample set based on similarity values, and a multidimensional scaling plot was subsequently generated using these data in SAS. The same procedure was followed for analyzing tRFLP profiles for similarity among samples at each site.

\section{Results}

Metal analysis

Multiple metals were elevated in sediments from Beaver Dam Creek Sites A and D relative to Meyers Branch (Table 2). Shipyard Creek sediments had higher concentrations of several metals compared with ACE Basin and LCP Chemical sediments, but LCP Chemical sediments were higher in mercury (Table 2).

\section{$16 S$ rRNA abundance}

For freshwater samples, 16S rRNA gene abundance did not differ between sites for biofilm samples, but there were significantly fewer $16 \mathrm{~S}$ rRNA copies at Site D in Corbicula, sediment and water column microhabitats (Figure 2a). 16S rRNA copies were significantly more abundant in sediment and water

Table 2 Sediment metal concentrations $\left(\mathrm{mg} \mathrm{kg}^{-1}\right)$ from reference and contaminated freshwater and estuarine samples

\begin{tabular}{|c|c|c|c|c|c|c|c|c|c|c|c|c|c|c|}
\hline Site & Туре & $\mathrm{Cr}$ & Co & $\mathrm{Ni}$ & $\mathrm{Cu}$ & $Z n$ & As & Se & $S r$ & $C d$ & $H g$ & $B e$ & $V$ & Mo \\
\hline Meyers Branch & Freshwater & BDL & 1.86 & 1.47 & 0.74 & 13.80 & BDL & 1.43 & BDL & 0.02 & BDL & BDL & 1.36 & BDL \\
\hline Beaver Dam Site D & Freshwater & 3.85 & 1.89 & 2.88 & 3.16 & 15.44 & 1.02 & 3.40 & BDL & 0.04 & BDL & 0.25 & 8.33 & BDL \\
\hline Beaver Dam Site A & Freshwater & BDL & 1.76 & 4.72 & 3.87 & 17.08 & 2.59 & 1.75 & 0.53 & 0.22 & 0.07 & 0.09 & 3.03 & BDL \\
\hline ACE basin & Estuarine & 53.68 & 7.39 & 16.38 & 9.03 & 51.35 & 10.81 & 2.31 & 66.00 & 0.24 & BDL & 1.60 & 56.04 & 0.82 \\
\hline LCP Chemical & Estuarine & 33.52 & 4.26 & 10.12 & 8.19 & 40.65 & 5.79 & BDL & 39.79 & 0.09 & 1.92 & 0.88 & 34.61 & 0.46 \\
\hline Shipyard Creek & Estuarine & 596.66 & 6.21 & 33.36 & 59.09 & 198.84 & 10.65 & BDL & 114.40 & 1.22 & BDL & 0.87 & 45.66 & 8.61 \\
\hline
\end{tabular}

Abbreviations: As, arsenic; BDL, below detection limit; Be, beryllium; Cd, cadmium; Co, cobalt; Cr, chromium; Cu, copper; Hg, mercury; Mo, molybdenum; Ni, nickel; Se, selenium; Sr, strontium; V, vanadium; Zn, zinc.

Estuarine values represent mean concentrations of five replicate samples collected during October 2005. 

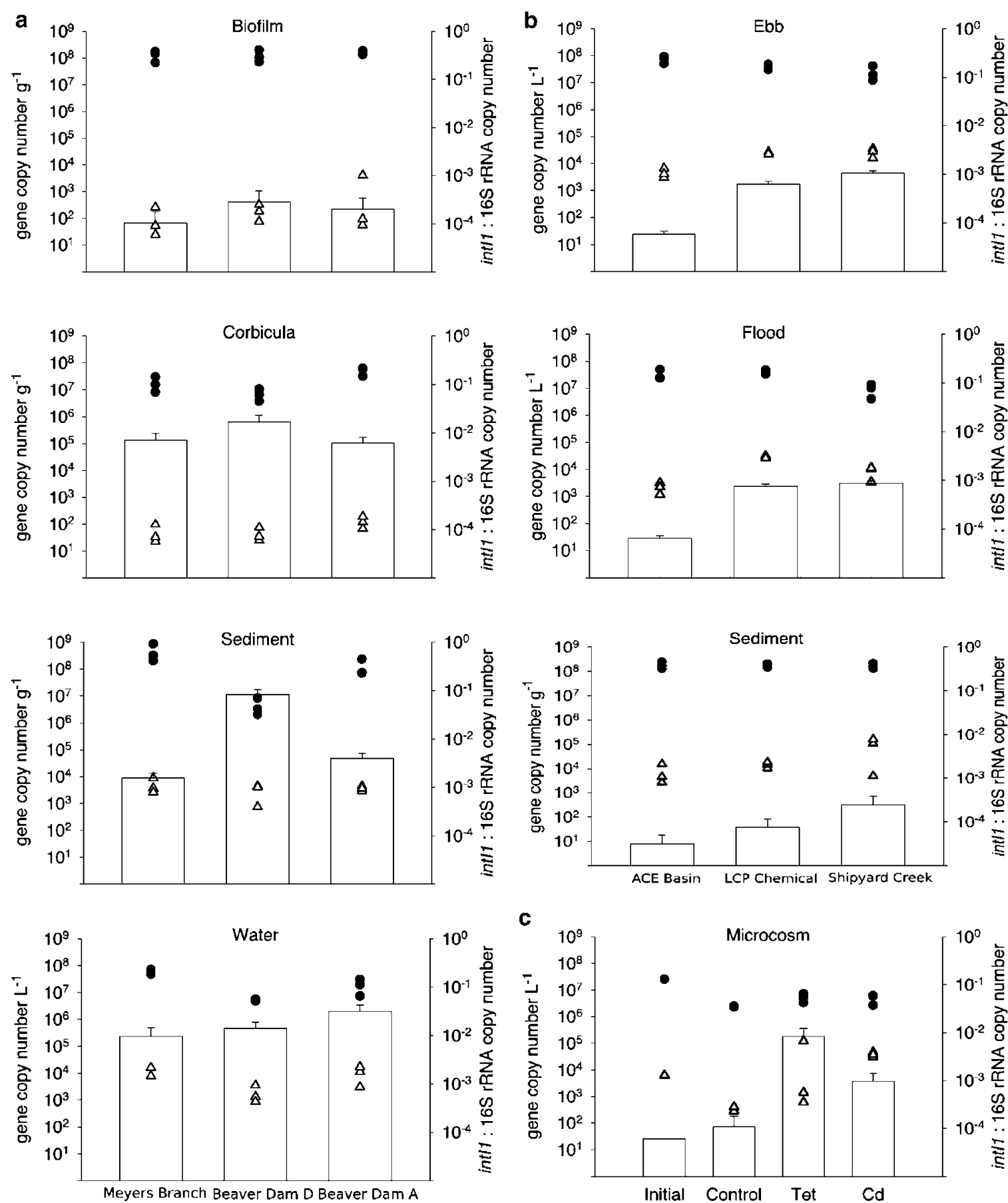

C

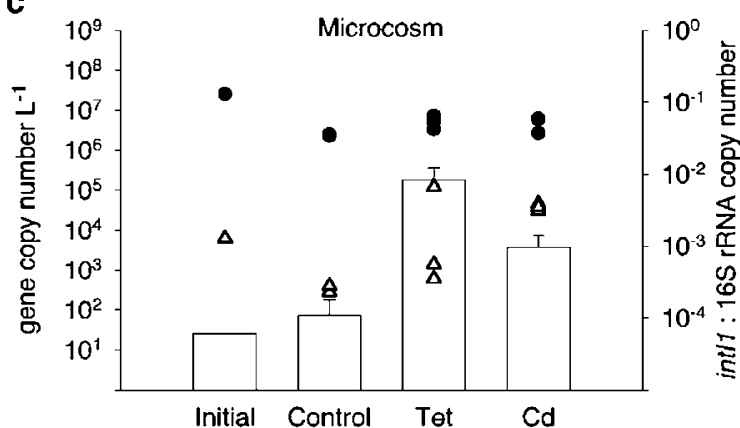

Figure $216 \mathrm{~S}$ rRNA copy number $(\bullet)$, class 1 integrase (intI1) copy number $(\triangle)$ and the 16S rRNA: intI1 copy number ratio for the various sites and microhabitats as assessed by quantitative PCR. (a) Savannah River Site freshwater microhabitats; (b) estuarine microhabitats; and (c) experimental microcosm.

column samples at Meyers Branch than at Site A, but this pattern was reversed for Corbicula samples. For estuarine sites, in both ebb and flood samples, there were significantly fewer copies of $16 \mathrm{~S}$ rRNA genes at the Shipyard Creek site compared with ACE Basin and LCP Chemical sites, but there were no site-specific differences among sediment samples (Figure 2b). 16S rRNA copy number was greatest in the initial samples but declined over the 7 days of incubation for all microcosms (Figure 2c). 16S rRNA qPCR efficiencies ranged between $100.2 \%$ and $105.3 \%$ among the sample types, with correlation coefficients between 0.90 and 0.96 for the standard calibration curves. Melt curve analysis displayed a single peak confirming the specificity of the reactions. 
intI1 relative abundance

The relative intI1 abundance was significantly greater in bacteria from contaminated sites compared with the reference site across the tested bacterial communities. The intI1/16S rRNA ratio was significantly lower for biofilm, sediment and water microhabitats at the reference riverine site, Meyers Branch, relative to the two contaminated sites; however, there was no statistical difference in the ratio for Corbicula samples among the three sites (Figure 2a). Copies of intI1 genes were significantly more abundant at Site D than Site A for sediment samples, while there was no statistical difference between the two sites for the other sampled microhabitats. Compared with the two contaminated estuarine sites, significantly fewer copies of intI1 were detected in ACE Basin for ebb, flood and sediment samples, while the ratio of intI1/16S rRNA was significantly greater in Shipyard Creek than LCP Chemical samples for ebb samples (Figure 2b). In microcosm samples, intI1 relative abundance was greatest in the cadmium treatment, followed by the tetracycline treatment, while there was no statistical difference between initial and control microcosms (Figure 2c). qPCR efficiencies ranged from $85.5 \%$ to $86.8 \%$, while standard curve correlation coefficients ranged from 0.910 to 0.982 . All retrieved intI sequences were highly similar to previously characterized intI1 genes and have been deposited in GenBank under the following accession numbers (EU43506-EU43511).

\section{Gene cassette structure}

Gene cassette richness (the number of unique gene cassette sizes) and Shannon diversity varied significantly among sites, but with no consistent pattern between contaminant-exposed and reference communities (Table 3). Richness and diversity were significantly greater in contaminant-exposed communities from the freshwater and microcosm samples. However, cassette richness and diversity were significantly greater in the reference site, ACE
Basin and LCP Chemical site than in Shipyard Creek. The composition of the gene cassette pool varied among sites and microcosms, as gene cassette profiles were more similar within rather than among each site or microcosm treatment (Table 3). Furthermore, replicates from each sample clustered together in comparison with replicates from other sites or treatments in a multidimensional scaling plot (Figure 3a).

\section{Gene cassette function}

Of the 46 sequenced gene cassettes obtained from total community DNA extracted from each sample type, 43 had predicted ORFs with start and stop codons in typical gene cassette orientation (Stokes et al., 2001), while the three with no obvious ORF were all less than $209 \mathrm{bp}$ in length. Gene cassette sequences have been deposited in GenBank under the following accession numbers: EU435312EU435354. Several ORFs had putative stop codons out of frame $(n=15)$ or stop codons in the middle of the predicted coding sequence $(n=8)$. The majority of gene cassette sequences contained ORFs that had no similar matches in GenBank at either the nucleotide or amino-acid level $(n=34)$. Only nine gene cassettes were similar to GenBank sequences at the amino-acid level (Table 4). Two gene cassettes were similar to previously detected gene cassettes, and four gene cassettes encoded functions that were similar to hypothetical proteins. No known antibiotic or metal resistance genes were recovered, but gene cassettes encoding proteins with similarity to proteins of known function included partial matches to magnesium chelatases, $N$-acetyltransferases and pantothenate synthetases. However, the CdMicrocosm_01 cassette likely underwent a frameshift as there was an inframe stop codon in the middle of the coding sequence, and no inframe stop at the end. The gene cassette encoding a product similar to pantothenate synthetases involved in vitamin $B_{5}$ synthesis had an inframe stop codon as did the InitMicrocosm_06 cassette.

Table 3 Gene cassette richness, diversity (Shannon), gene cassette and tRFLP similarity (Chao's abundance-based Jaccard similarity) both within a site and among sites for sediment samples as calculated in EstimateS for each of the three sample groups (Colwell, 2005)

\begin{tabular}{|c|c|c|c|c|c|c|}
\hline Sample & $\begin{array}{l}\text { Cassette } \\
\text { richness }\end{array}$ & $\begin{array}{l}\text { Cassette } \\
\text { diversity }\end{array}$ & $\begin{array}{l}\text { Cassette similarity } \\
\text { within group }\end{array}$ & $\begin{array}{l}\text { Cassette similarity } \\
\text { among groups }\end{array}$ & $\begin{array}{l}\text { tRFLP similarity } \\
\text { within group }\end{array}$ & $\begin{array}{c}\text { tRFLP similarity } \\
\text { among groups }\end{array}$ \\
\hline Meyers branch & $202(4.2)$ & 4.0 & $0.77(0.05)$ & $0.30(0.02)$ & $0.25(0.04)$ & $0.28(0.08)$ \\
\hline Beaver dam site D & $259(5.9)$ & 4.9 & $0.48(0.12)$ & $0.31(0.03)$ & $0.29(0.01)$ & $0.25(0.07)$ \\
\hline Beaver dam site A & $268(5.5)$ & 4.6 & $0.77(0.02)$ & $0.36(0.02)$ & $0.27(0.04)$ & $0.26(0.09)$ \\
\hline ACE basin & $255(6.6)$ & 4.2 & $0.91(0.03)$ & $0.66(0.05)$ & $0.88(0.03)$ & $0.67(0.17)$ \\
\hline LCP chemical & $255(6.8)$ & 4.5 & $0.86(0.04)$ & $0.69(0.06)$ & $0.75(0.07)$ & $0.71(0.17)$ \\
\hline Shipyard creek & $234(5.0)$ & 4.3 & $0.90(0.01)$ & $0.59(0.07)$ & $0.63(0.30)$ & $0.60(0.19)$ \\
\hline Initial & 21 (NA) & 2.2 & NA & $0.052(0.02)$ & NA & $0.48(0.16)$ \\
\hline Control & $30(5.2)$ & 3.1 & $0.07(0.04)$ & $0.027(0.01)$ & $0.48(0.15)$ & $0.45(0.13)$ \\
\hline Cadmium & $91(8.3)$ & 4.1 & $0.04(0.04)$ & $0.041(0.01)$ & $0.77(0.09)$ & $0.52(0.13)$ \\
\hline Tetracycline & $95(7.6)$ & 3.6 & $0.11(0.09)$ & $0.025(0.01)$ & $0.54(0.31)$ & $0.53(0.14)$ \\
\hline
\end{tabular}

Abbreviations: NA, not applicable because there is only one initial sample; tRFLP, terminal restriction length polymorphism.

Values in parentheses represent 1 s.d. $(n=3)$. 
Gene Cassette
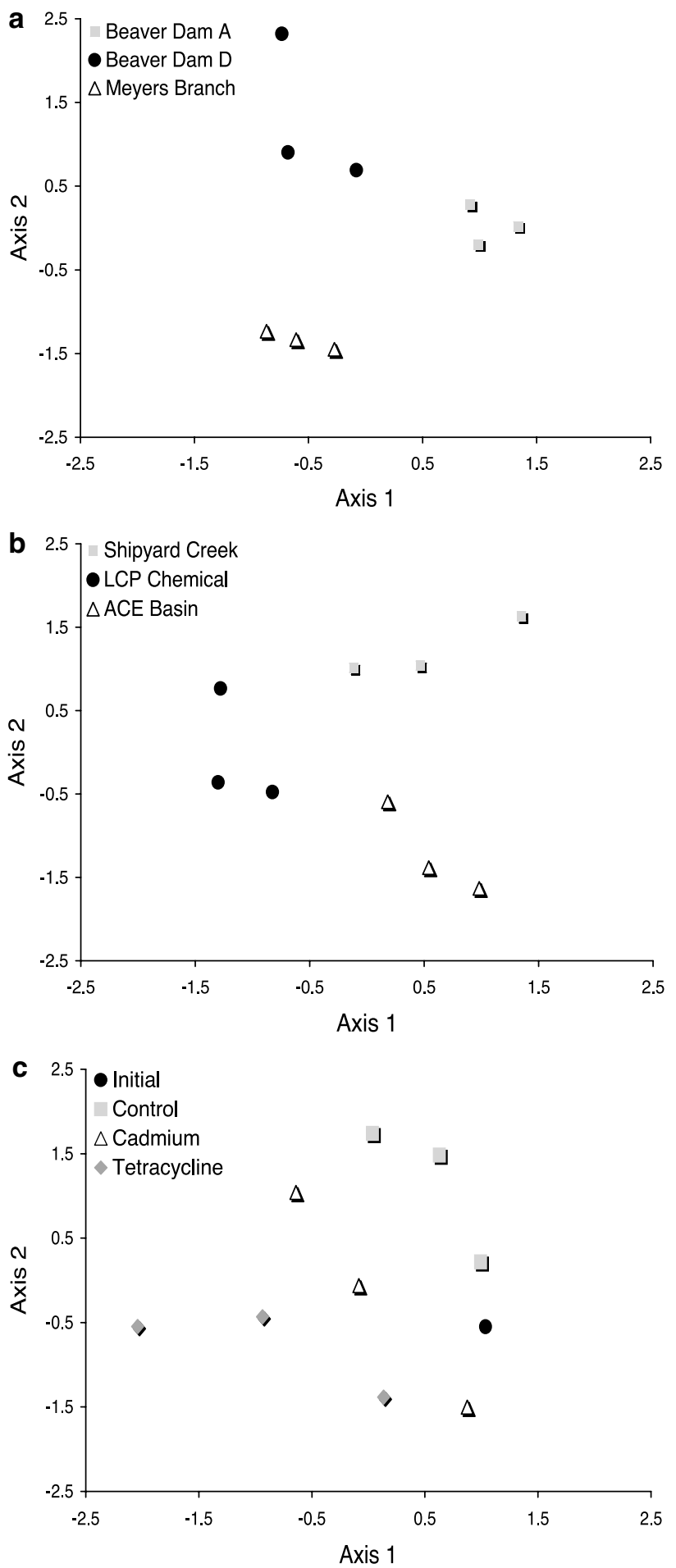

tRFLP
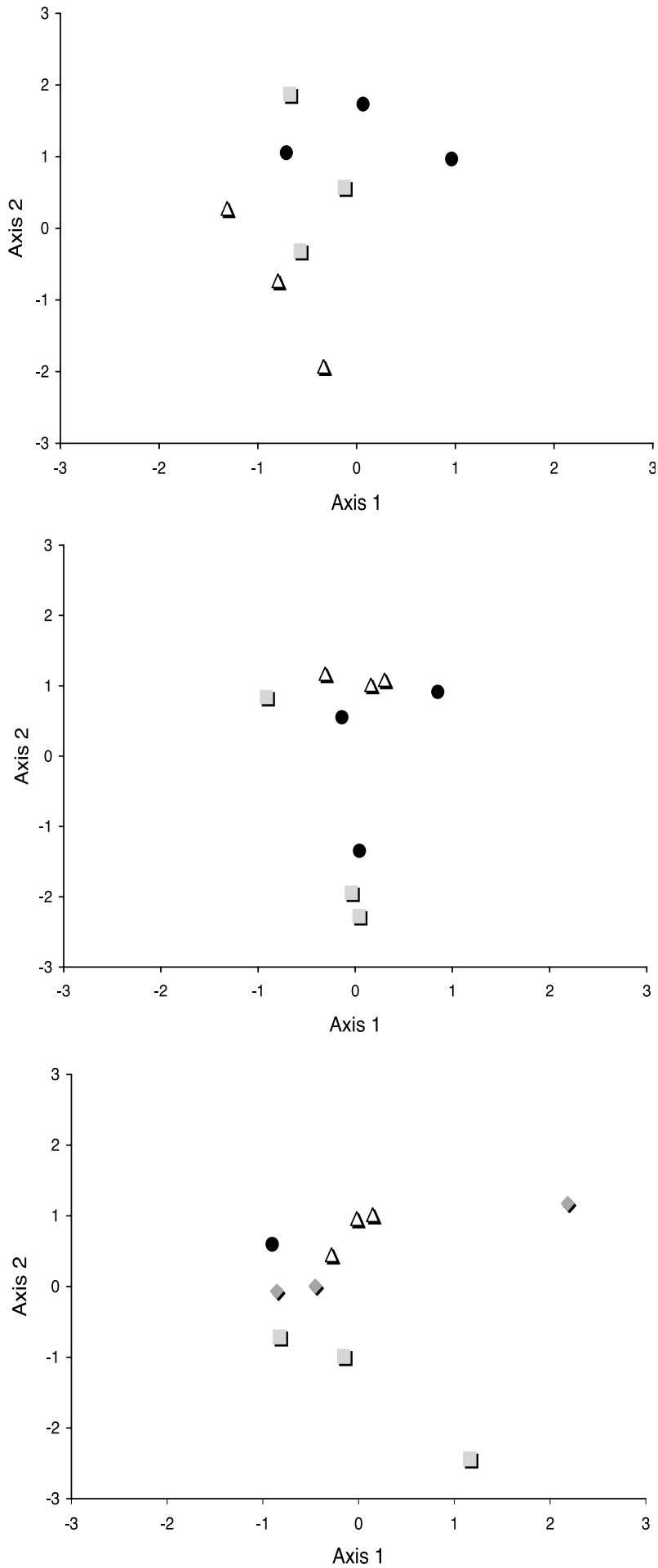

Figure 3 Multidimensional scaling plots of sediment gene cassette pool as assessed by amplifying gene cassettes with HS286 and HS287 primers (Figure 1), and bacterial community structure as assessed by 16S rRNA terminal restriction fragment length polymorphism (tRFLP) analysis, based on a distance matrix calculated from Chao's abundance-based Jaccard similarity (see Table 2 for similarity values). (a) Savannah River Site freshwater microhabitats; (b) estuarine microhabitats; and (c) experimental microcosm.

tRFLP community similarity

Bacterial community composition was not identifiably distinct between sites as assessed by the similarity of $16 \mathrm{~S}$ rRNA tRFLP profiles, where Chao's abundance-based Jaccard similarity values indicate that similarity was not greater within a site compared with that among the sites (Table 3) as analyzed separately for each of the three sample sets. 
Additionally, replicates from each site did not cluster together in a multidimensional scaling plot (Figure 3b).

\section{Discussion}

Class 1 integron abundance

Genetic elements involved in the acquisition of exogenous sources of DNA were more abundant in contaminant-exposed bacterial communities across a variety of freshwater and estuarine microbial habitats and in experimental microcosms where metal and antibiotic exposure was manipulated. That this effect of industrial contamination on intI1 gene abundance was observed across multiple bacterial communities in multiple types of ecosystems indicates its generality. In this study, the intI1 gene was relatively more abundant in Site D than in Site A in the contaminated freshwater stream counter to the prediction that intI1 would be most abundant in the most contaminated site. Metal concentrations were elevated at Site D on the sampling date likely due to both a period of increased stream discharge associated with the coal-fired plant operations (data not shown) and the long-term cumulative effects of sediment transport from more contaminated sites upstream. Regardless of variance within Beaver Dam Creek, intI1 was consistently more abundant across multiple microhabitats in comparison with the reference site, Meyers Branch.

Culture-based and molecular estimates of intI1 abundance in bacteria of environmental origin indicate that between $1 \%$ and $10 \%$ of bacteria possess these genes (C Baker-Austin, unpublished data; Nandi et al., 2004; Boucher et al., 2007), although Biyela et al. (2004) found class 1 integrons in over $50 \%$ of isolates with multiple drug resistances from an urban South African river. Variation in the proportion of a bacterial community possessing class 1 integrons outside of clinical settings is likely to be the result of several factors including (1) distance to an enriched source of class 1 integrons (for example, sewage treatment plant); (2) integron dispersal ability (for example, mobilization of the integron via physical linkage to a plasmid or transposon); (3) the taxonomic composition of the community; (4) horizontal gene transfer potential in a given habitat; and (5) intensity of selective pressure favoring the maintenance of genes contained within the integron.

To date, class 1 integrons have primarily been characterized from $\gamma$-proteobacteria of clinical origin, but have more recently been detected in environmental bacteria from diverse habitats and taxonomic relationship. For example, based on a BLASTN search of 759 bacterial genomes (completed and whole-genome shotgun projects) in the Microbial Genome Resources database (http://www.ncbi.nlm.nih.gov/genomes/MICROBES/ 
microbial_taxtree.html), eight genomes (1.1\%) yielded sequences similar to intI1 (E-value cutoff: $1 \mathrm{e}^{-50}$ ). Seven of these genomes were from enteric $\gamma$-proteobacterial pathogens of clinical origin, while the exception to this was the Gram-positive human pathogen Corynebacterium diphtheriae (Actinobacteria) (Supplementary Table 1). In a BLASTN search of all GenBank bacterial sequences, more than 300 unique nucleotide sequences produced similar alignments to intI1 ( $E$-value cutoff: $\left.1 \mathrm{e}^{-50}\right)$. Again, the majority of these were from plasmids and transposons in clinical isolates of Gram-negative proteobacteria pathogens reflecting the bias in the database toward pathogenic bacteria and antibiotic resistance studies. However, a broader group of bacteria possess these elements as evidenced by Nandi et al. (2004) detecting intI1 in Gram-positive bacteria and the recent description by Stokes et al. (2006) of four nonpathogenic soil bacteria (all $\beta$-proteobacteria) possessing class 1 integrons. A BLASTN search of archaeal sequences found no matches to intI1 indicating that to date no class 1 integrons have been detected in Archaea (date of analyses: 27 March 2007). Thus sequence database evidence to date suggest that class 1 integrons are concentrated in Gram-negative $\gamma$-proteobacteria, but this picture will likely change with sequence analysis of bacteria from terrestrial and aquatic systems.

Elevated class 1 integron abundance in industrially contaminated sites can either be the result of selection for the integron itself (the ability to acquire and insert new genetic material in a site-specific location), adaptive gene cassettes contained within integrons (direct selection) or other genetic elements to which the integron is physically linked (coselection). In support of the last hypothesis, class 1 integrons are frequently detected on larger MGEs including insertion sequence common regions, transposons and plasmids (Tennstedt et al., 2003, 2005; Stokes et al., 2006; Toleman et al., 2006a, b; Walsh, 2006) that contain genes encoding other functions. A good example of this is Tn21, a transposon containing a mercury resistance transposon in which a class 1 integron is embedded (Liebert et al., 1999). Selective pressures favoring the maintenance of genes within these genetic elements (for example, metal contamination maintaining metal resistance genes) may therefore maintain other genes including integrons that are physically linked. However, what regulates integron-mediated gene cassette recombination, and the expression of cassette-associated genes is yet to be fully understood, thereby limiting a rigorous assessment of the mechanisms contributing to the increased abundance of intI1 genes observed in metal-contaminated sites.

\section{Gene cassette structure and function}

The effects of industrial contamination on gene cassette pool richness and diversity are equivocal, as the riverine and microcosm data suggest that this selective pressure increases the richness and diversity of the gene cassette pool, whereas this pattern was not observed in the estuarine sites where cassette richness and diversity was lower at Shipyard Creek. We predicted that contamination would have a homogenizing effect on the gene cassette pool, as selective pressures would favor the propagation of cassettes conferring a selective advantage (Turner et al., 2002), but alternatively it may be that the sampled sites are too heterogeneous to favor the dominance of a few cassettes.

The analysis of cassette richness using these methods is likely to underestimate gene cassette richness. This is in large part because the primers used do not recover all integron-associated gene cassettes (Michael et al., 2004). Other potential biases relate to the use of gene cassette size as a proxy for distinguishing between different cassettes. Previously, Michael et al. (2004) detailed this potential bias, where the same cassette size class can contain multiple cassettes. However, this problem is not unique to this method, as the same limitation is present in techniques such as tRFLP and DGGE. These biases result in richness values that underestimate the true number of unique gene cassettes in a bacterial community, but what is still apparent is that gene cassettes are a diverse genetic resource for bacterial evolution in the environment.

Similarity patterns indicate that the gene cassette pool at each site or microcosm treatment was more similar in gene cassette size composition and relative abundance compared with the other sites for each sample set. This finding likely reflects differences in selective pressures at each site maintaining a different pool of cassettes. Alternatively, gene cassette profiles could reflect taxonomic or biogeographic artifacts, but 16S rRNA bacterial community fingerprints as assessed by tRFLP analysis indicate that overall community structure was not distinct among sites within each of the three sample sets. This strengthens the conclusion that gene cassette pools were distinct at each site because of differential selective pressure. However, tRFLP fingerprinting analysis is a relatively course metric of community similarity, which can mask finer scale taxonomic variation in bacterial community composition, and biogeography may still have an effect through dispersal limitation of gene cassettes between sites or through variations in gene cassette composition entering each site due to differences in watershed drainages.

One key to assess whether gene cassettes are selected for at the various sites is to identify the potential function of their genes. An assessment of whether any of the most abundant gene cassettes is of potential adaptive significance is hampered by the lack of recovery of the most abundant cassette sizes, and by the fact that most sequenced cassettes were novel. Of interest was the fact that several gene cassettes likely encode nonfunctional proteins due 
to frameshifts, and inframe stop codons, suggesting that they are not encoding a protein under selection. Those cassettes that are similar to GenBank sequences are of mostly unknown function, whereas the three sequences were similar to proteins with identified function, although were not associated with known metal- or antibiotic resistance genes. Two cassettes (Initial Microcosm_02 and SRS Sed_01) encoded proteins that had low-level similarity at the amino-acid level to products from gene cassettes previously recovered, further demonstrating that gene cassettes themselves can evolve. The majority of sequenced gene cassettes are novel, as recovered using gene cassette PCR, but this method does not allow for a characterization of the integron context in which they are associated. Furthermore, this finding is consistent with previous surveys of environmental gene cassettes supporting the hypothesis that this pool is a diverse and distinct genetic resource from that found statically in bacterial chromosomes (Boucher et al., 2007).

\section{Summary}

Integrons are ubiquitous in bacterial communities regardless of whether industrial contamination is present, demonstrating that these MGEs play a substantial role in the acquisition of new genetic material in environmental bacteria. That they were more abundant in sites with contamination across a variety of habitats and ecosystems suggests that bacteria at these sites have a higher potential for gene exchange, whether it is for the acquisition of antibiotic resistance gene cassettes or cassettes of unknown function. The gene cassette pool is a diverse resource available for bacterial acquisition via horizontal gene transfer, whereas the composition of the pool reflects selective pressures at each site. Whether these findings are applicable to other MGEs besides class 1 integrons remains to be tested, and where further study would enhance our understanding of the effect of stress on evolutionary processes in bacteria.

\section{Acknowledgements}

This work was supported by the US Environmental Protection Agency's Science to Achieve Results (STAR) fellowship, US National Science Foundation's East Asia and Pacific Summer Institute (EAPSI) fellowship, and the Australian Academy of Science to Wright; and the National Oceanographic and Atmospheric Administration (NOAA) award NA04OAR4600198 to Stepanauskas. Additional support was provided from the US Department of Energy Financial Assistance Award DE-FC09-96SR18546 to the University of Georgia Research Foundation.

\section{References}

Altschul SF, Gish W, Miller W, Myers EW, Lipman DJ. (1990). Basic local alignment search tool. J Mol Biol 215: 403-410.
Baker GC, Smith JJ, Cowan DA. (2003). Review and re-analysis of domain-specific $16 \mathrm{~S}$ primers. J Microbiol Methods 55: 541-555.

Biyela PT, Lin J, Bezuidenhout CC. (2004). The role of aquatic ecosystems as reservoirs of antibiotic resistant bacteria and antibiotic resistance genes. Water Sci Technol 50: 45-50.

Boucher Y, Douady CJ, Papke RT, Walsh DA, Boudreau ME, Nesbø CL et al. (2003). Lateral gene transfer and the origins of prokaryotic groups. Annu Rev Genet 37: 283-328.

Boucher Y, Labbate M, Koenig JE, Stokes HW. (2007). Integrons: mobilizable platforms that promote genetic diversity in bacteria. Trends Microbiol 15: 301-309.

Colwell RK. (2005). EstimateS: statistical estimation of species richness and shared species from samples. Version 7.5. User's Guide and Application; published at: http://purl.oclc.org/estimates.

Comas I, Moya A, Azad RK, Lawrence JG, Gonzalez-Candelas F. (2006). The evolutionary origin of Xanthomonadales genomes and the nature of the horizontal gene transfer process. Mol Biol Evol 23: 2049-2057.

Dahlberg C, Bergstrom M, Hermansson M. (1998). In situ detection of high levels of horizontal plasmid transfer in marine bacterial communities. Appl Environ Microbiol 64: 2670-2675.

DeWoody JA, Schupp J, Kenefic L, Busch J, Murfitt L, Keim P. (2004). Universal method for producing ROX-labeled size standards suitable for automated genotyping. Biotechniques 37: 348-352.

Dobrindt U, Hochhut B, Hentschel U, Hacker J. (2004). Genomic islands in pathogenic and environmental microorganisms. Nat Rev Microbiol 2: 414-424.

Doolittle WF, Bapteste E. (2007). Pattern pluralism and the Tree of Life hypothesis. Proc Natl Acad Sci USA 104: 2043-2049.

Fierer N, Jackson JA, Vilgalys R, Jackson RB. (2005). Assessment of soil microbial community structure by use of taxon-specific quantitative PCR assays. Appl Environ Microbiol 71: 4117-4120.

Frost LS, Leplae R, Summers AO, Toussaint A. (2005). Mobile genetic elements: the agents of open source evolution. Nat Rev Microbiol 3: 722-732.

Gogarten JP, Townsend JP. (2005). Horizontal gene transfer, genome innovation and evolution. Nat Rev Microbiol 3: 679-687.

Holmes AJ, Gillings MR, Nield BS, Mabbutt BC, Nevalainen KM, Stokes HW. (2003). The gene cassette metagenome is a basic resource for bacterial genome evolution. Environ Microbiol 5: 383-394.

Kunin V, Goldovsky L, Darzentas N, Ouzounis CA. (2005). The net of life: reconstructing the microbial phylogenetic network. Genome Res 15: 954-959.

Lambertsen LM, Molin S, Kroer N, Thomas CM. (2004). Transcriptional regulation of pWW0 transfer genes in Pseudomonas putida KT2440. Plasmid 52: 169-181.

Liebert CA, Hall RM, Summers AO. (1999). Transposon Tn21, flagship of the floating genome. Microbiol Mol Biol Rev 63: 507-522.

McArthur J, Tuckfield RC. (2000). Spatial patterns in antibiotic resistance among stream bacteria: effects of industrial pollution. Appl Environ Microbiol 66: 3722-3726.

Michael CA, Gillings MR, Holmes AJ, Hughes L, Andrew NR, Holley MP et al. (2004). Mobile gene cassettes: a fundamental resource for bacterial evolution. Am Nat 164: 1-12. 
Nandi S, Maurer JJ, Hofacre C, Summers AO. (2004). Gram-positive bacteria are a major reservoir of Class 1 antibiotic resistance integrons in poultry litter. Proc Natl Acad Sci USA 101: 7118-7122.

Nemergut DR, Martin AP, Schmidt SK. (2004). Integron diversity in heavy-metal-contaminated mine tailings and inferences about integron evolution. Appl Environ Microbiol 70: 1160-1168.

Nield BS, Holmes AJ, Gillings MR, Recchia GD, Mabbutt BC, Nevalainen KM et al. (2001). Recovery of new integron classes from environmental DNA. FEMS Microbiol Lett 195: 59-65.

O’Brien TF. (2002). Emergence, spread, and environmental effect of antimicrobial resistance: how use of an antimicrobial anywhere can increase resistance to any antimicrobial anywhere else. Clin Infect Dis 34: S78-S84.

Ochman H, Lawrence JG, Groisman EA. (2000). Lateral gene transfer and the nature of bacterial innovation. Nature 405: 299-304.

Sambrook J, Russell DW. (2000). Molecular Cloning: A Laboratory Manual, 3rd edn. Cold Spring Harbor Laboratory Press: Cold Spring Harbor.

Smalla K, Haines AS, Jones K, Krögerrecklenfort E, Heuer H, Schloter $M$ et al. (2006). Increased abundance of IncP-1 beta plasmids and mercury resistance genes in mercury-polluted river sediments: first discovery of IncP-1 beta plasmids with a complex mer transposon as the sole accessory element. Appl Environ Microbiol 72: 7253-7259.

Smalla K, Sobecky PA. (2002). The prevalence and diversity of mobile genetic elements in bacterial communities of different environmental habitats: insights gained from different methodological approaches. FEMS Microbiol Ecol 42: 165-175.

Sobecky PA. (1999). Plasmid ecology of marine sediment microbial communities. Hydrobiologia 401: 9-18.

Stepanauskas R, Glenn TC, Jagoe CH, Tuckfield RC, Lindell AH, King CJ et al. (2006). Coselection for microbial resistance to metals and antibiotics in freshwater microcosms. Environ Microbiol 8: 1510-1514.

Stokes HW, Hall RM. (1989). A novel family of potentially mobile DNA elements encoding site-specific geneintegration functions: integrons. Mol Microbiol 3: 1669-1683.
Stokes HW, Holmes AJ, Nield BS, Holley MP, Nevalainen KM, Mabbutt BC et al. (2001). Gene cassette PCR: sequence-independent recovery of entire genes from environmental DNA. Appl Environ Microbiol 67: 5240-5246.

Stokes HW, Nesbo CL, Holley M, Bahl MI, Gillings MR, Boucher Y. (2006). Class 1 integrons potentially predating the association with Tn402-like transposition genes are present in a sediment microbial community. J Bacteriol 188: 5722-5730.

Tennstedt T, Szczepanowski R, Braun S, Puhler A, Schluter A. (2003). Occurrence of integron-associated resistance gene cassettes located on antibiotic resistance plasmids isolated from a wastewater treatment plant. FEMS Microbiol Ecol 45: 239-252.

Tennstedt T, Szczepanowski R, Krahn I, Puhler A, Schluter A. (2005). Sequence of the 68,869 bp IncP-1 alpha plasmid pTB11 from a waste-water treatment plant reveals a highly conserved backbone, a Tn402-like integron and other transposable elements. Plasmid 53: 218-238.

Thorsted PA, Macartney DP, Akhtar P, Haines AS, Ali N, Davidson $\mathrm{P}$ et al. (1998). Complete sequence of the IncP beta plasmid R751: implications for evolution and organisation of the IncP backbone. J Mol Biol 282: 969-990.

Toleman MA, Bennett PM, Walsh TR. (2006a). Common regions e.g. orf513 and antibiotic resistance: IS91-like elements evolving complex class 1 integrons. J Antimicrob Chemother 58: 1-6.

Toleman MA, Bennett PM, Walsh TR. (2006b). ISCR elements: novel gene-capturing systems of the 21st century? Microbiol Mol Biol Rev 70: 296-316.

Turner SL, Bailey MJ, Lilley AK, Thomas CM. (2002). Ecological and molecular maintenance strategies of mobile genetic elements. FEMS Microbiol Ecol 42: 177-185.

van Elsas JD, Bailey MJ. (2002). The ecology of transfer of mobile genetic elements. FEMS Microbiol Ecol 42: 187-197.

Walsh TR. (2006). Combinatorial genetic evolution of multiresistance. Curr Opin Microbiol 9: 476-482.

Wright MS, Peltier GL, Stepanauskas R, McArthur JV. (2006). Bacterial tolerances to metals and antibiotics in metal-contaminated and reference streams. FEMS Microbiol Ecol 58: 293-302.

Supplementary Information accompanies the paper on The ISME Journal website (http://www.nature.com/ismej) 